\title{
Representasi Ukhuwah Islamiah dalam Film Pendek
}

\author{
Linda Maulidah $^{1 *}$, Atjep Muhlis ${ }^{1}$, Uwes Fatoni ${ }^{1}$ \\ ${ }^{1}$ Jurusan Komunikasi dan Penyiaran Islam, Fakultas Dakwah dan Komunikasi, UIN Sunan \\ Gunung Djati, Bandung \\ *Email : lindamaulida1@gmail.com
}

\begin{abstract}
ABSTRAK
Penelitian ini bertujuan untuk mengetahui adegan yang merepresentasikan adanya Ukhuwah Islamiah, tentang bagaimana adegan ukhuwah Islamiah ditinjau dari Semiotika model Charles Sanders Piece. Penelitian ini merupakan penelitian kualitatif dengan metode analisis Semiotika Charles Piece yang mengkaji dengan konsep Segitiga makna yaitu Representamen/tanda, Interpretant dan object. Hasil penelitian ini menemukan 14 representament adegan yang merepresentasi ukhuwah Islamiah dalam film Cinta dalam Ukhuwah. Adapun object yang merepresentasikan ukhuwah Islamiah adalah nuansa-nuansa dari ekspresi tokoh atau keadaan-keadaan yang sedang tokoh lakukan. Intrepretant yang didapat ialah bahwa dalam film tersebut menunjukan adanya faktor perusak dan penguat ukhuwah Islamiah dari perilaku-perilaku yang ditunjukan dari representament dan object.
\end{abstract}

Kata Kunci : Film; Semiotika; Ukhuwah Islamiah

\section{ABSTRACT}

Purpuses of the reseach is to know a scene that represent existence of Ukbuwah Islamiah. About how the scene of the Ukbuwah islamiah is viewed from the semiotics model of Charles sanders. This research is a qualitative study with a Semiotics analytical methods of Charles peirce, that examine the concept of the triangle meaning it is representament/sign, interpretant, and object. The results of this study Find 14 representament scenes that represent about ukhuwah Islamiah. As for the object representing ukbuwah Islamiah are nuances of a character's expression, Or the circumstances being where people are. Intepretant is obtained Or the circumstances being where people are. Interpretant is obtained in the film, it shows the destructive factor and the booster of ukhuwah Islamiah from the attitudes indicated by the representament and object.

Keywords: Movie; Semiotic; Ukhwwah Islamiah 
Maulidah L, Muhlis A \& Fatoni U

\section{PENDAHULUAN}

Dunia saat ini dihadapkan dengan era perkembangan teknologi dan komunikasi yang canggih, terkhusus di Indonesia, perkembangan teknologi dan komunikasi yang canggih ini telah mempengaruhi pola hidup masyarakat akibat informasi yang diterimanya, terlebih setelah populernya media komunikasi massa, atau yang sering disebut dengan media massa. Media massa telah hadir memberikan kemudahan untuk menyampaikan berbagai informasi dengan cepat dan menyeluruh kepada khalayak yang tersebar dimanapun, sehingga masyarakat dapat dengan mudah menerima dan kemudian mempengaruhi pola pikir dan pola hidup mereka. Teknologi media massa merupakan perkembangan yang mampu mengakibatkan perubahan budaya karena dengan bantuan teknologi pesan-pesan lebih mudah memasuki pikiran khalayak, kemudian memberikan kesan yang lebih mendalam (Liliweri, 1991: 81).

Media massa memudahkan manusia untuk saling berhubungan dan menerima informasi atau menerima pesan, khususnya dalam bidang dakwah, karena kehadiran media massa sangat efektif dimanfaatkan untuk media dakwah. Salah satu media dakwah yang efektif diiterima masyarakat adalah film.

Mubasyaroh (2014: 14) mengemukakan film sebagai media dakwah memiliki keunggulan dibanding media lain Keunggulan tersebut diantaranya karena film memiliki tampilan yang berbeda yaitu audio visual dan cerita yang dikemas semenarik mungkin, sehingga khalayak akan lebih tertarik.

Sekarang ini, dari tahun ke tahun banyak sekali bermunculan film-film yang bernuansakan Islam. Banyak industri perfilman yang membuat film-film Islam yang kemudian film tersebut banyak diminati masyarakat. Film tersebut diantaranya : Perempuan Berkalung Sorban dan Ketika Cinta Bertasbih (2009), Sang Pencerah (2010), Tanda Tanya (2011), Negri 5 Menara (2012), Sang Kyai, 99 Cahaya di Langit Eropa, Ayat-ayat Cinta (2013), Assalamu'alaikum Beijing (2014), Surga yang tak dirindukan, Alif Lam Mim (2015), Cahaya Cinta Pesantren (2016), dan Syaikh Abu Bakar (2017). Tidak hanya dalam industri perfilman komersil, film dakwah juga banyak bermunculan di media Youtube, dan sengaja diproduksi untuk keperluan dakwah, salah satunya dalam akun youtube filmmakermuslim. Mereka sengaja memproduksi film setiap bulan khusus untuk tujuan dakwah.

Film-film dakwah di atas tentu memiliki sebuah pesan keislaman, baik pesan itu disampaikan secara langsung maupun secara tak langsung. Diantaranya ialah pesan ukhuwah Islamiah Ukhuwah Islamiah sangatlah penting. Umat Islam seluruh dunia dituntut untuk saling bersaudara, dan tidak saling terpecah.

Akan tetapi kini isu perpecahan umat Islam banyak terjadi, dan salah satu faktornya adalah akibat tidak adanya kesadaran rasa ukhuwah Islamiah dalam diri seseorang.

Ukhuwah dan Persatuan seoal-olah menjadi prospek yang sulit digapai, 
sementara perpecahan menjadi problema yang nyaris menimpa semua kalangan umat. Contoh kecil, sekarang ini sering terjadi keributan baik di media sosial ataupun di lingkungan sekitar akibat perbebedaan pemahaman atau perbedaan pendapat, hingga saling menjatuhkan dan bahkan menghujat. Jika seseorang sadar akan keharusan ukhuwah Islamiah maka tidak akan terjadi hal seperti itu, karena alasan terkuat agar umat bisa bersatu adalah dengan adanya ukhuwah Islamiah yang artinya keharmonisan bermasyarakat khususnya bagi masyarakat muslim satu dengan muslim yang lainnya (Aminah, 2015: 47).

Mengingat betapa pentingngnya ukhuwah islamiah tersebut, maka Penelitian ini sengaja mengangkat pencarian tanda tentang ukhuwah Islamiah. Di setiap film tentu terdapat tanda-tanda dan tanda tersebut tentu akan menghasilkan makna, tanda yang muncul dari film adalah berupa gambar dan suara, karena film disampaikan melalui audio visual. Tanda-tanda yang berkaitan dengan Ukhuwah Islamiah ini dapat diketahui dengan diteliti melaui pendekatan semiotika/

Beberapa penelitian terdahulu mengkaji film melalui semiotika, diantaranya Pertama karya Aflahah tahun 2014 dengan judul Analisis Semiotika Makna Jihad dalam Film Sang Kyai Karya Rako Prijanto, penelitian ini merepresentasikan konsep jihad lewat tanda-tanda yang disebut oleh Barthes sebagai konotasi, denotasi, dan mitos. Kedua karya Lidya Ivana tahun 2013 dengan judul Analisis Semiotika pada Film Laskar Pelangi. menggunakan semiotika teori dari Ferdinand De Saussure serta menganalisis data berdasarkan Kamus, Ideologi, Frame Work Budaya dan Interpretan Kelompok. Ketiga karya Asriyanti tahun 2015 dengan judul Pesan Dakwah Melalui Media Sosial Youtube (Analisis Semiotik. Film Pendek Ramadhan Halal Yayasan Darul Qur'an).

Penelitian ini mengkaji film Cinta dalam Ukhuwah dengan pencarian tanda Ukhuwah Islamiah melalui analisis Semiotika Charles Sanders Peirce. Film Cinta dalam Ukhuwah secara tidak langsung memberi pesan dakwah berkaitan dengan pentingnya ukhuwah Islamiah.

Menyadarkan rasa ukhuwah Islamiah merupakan bagian dari pesan dakwah, dakwah sendiri menurut Toha Yahya Umar (Tajiri, 2015: 16) artinya mengajak manusia kepada jalan yang benar sesuai dengan ajaran Allah degan cara bijaksana. Maka jelas menyadarkan seseorang agar melakukan ukhuwah Islamiah adalah salah satu tugas dakwah, karena itu merupakan pesan ajaran yang diperintahkankan oleh Islam.

Film Cinta dalam Ukhuwah diproduksi oleh film maker muslim yang didukung oleh yayasan PPPA Daarul Quran, dan telah ditonton di Youtube sebanyak 174.007 kali (Part I), 154.329 kali (Part II), dan 115,265 kali (Part III). (diakses tanggal 8 Maret 2018 pukul 17:40).

Film yang diviralkan di Youtube ini mengangkat tema persahabatan dalam perbedaan, yang mengedepankan ukhuwah. Dalam film ini berkisahkan 
Maulidah L, Muhlis A \& Fatoni U

sekelompok anak muda yang hidup di satu pesantren dan kemudian setelah lulus pesantren mereka kuliah di universitas yang sama, walaupun terjadi banyak konflik namun bagaimana caranya menyikapi perbedaan dengan cinta dan rasa persaudaraan yang hakiki.

Dari upaya-upaya yang dilakukan untuk menyikapi perbedaan sehingga menjadi terwujud ukhuwah Islamiah di film tersebut, mmaka menjadi menarik jika ditelusuri tanda-tanda apa yang merepresentasikan Ukhuwah Islamiah maelaui analisis semiotika.

Semiotika merupakan kajian mengenai tanda dan bagaimana tanda itu bekerja, sebuah tanda adalah yang bersifat fisik dan mengacu pada sesuatu diluar darinya yang disebut dengan makna. Dari sekian banyak jenis analisis Semiotika, dipilih Semiotik Charles Sanders Pierce. Semiotik Charles Sanders Piercemempunyai konsep Segitiga makna, yaitu diantaranya ada Representament/tanda, Interpretant, dan object. Ketiga istilah tersebut hanya dapat difahami dalam keterkaitannya dengan satu sama lain (Fiske, 2012: 70).

Sebuah Tanda mengacu pada suatu hal di luar dari Objek, dan kemudian difahami oleh seseorang bahwa tanda memiliki interpretant berupa efek yang cukup menentukan di dalam benak pengguna interpertant yaitu sebuah konsep mental yang diproduksi oleh tanda tersebut. Film Cinta dalam Ukhuwah dianalisis menggunakan konsep segitiga makna tersebut, dengan mencari makna yang merepresentasikan konsep Ukhuwah Islamiah.

Berdasarkan latar belakang tersebut, penelitian ini memiliki tiga rumusan masalah, yaitu 1) Apa saja Representament dalam film Cinta dalam Ukhuwah yang merepresentasikan Ukhuwah Islamiah? 2) Bagaimana Object Ukhuwah Islamiah dalam film Cinta dalamUkhuwah? 3) Bagaimana Interpretant Ukhuwah Islamiah dalam Film Cinta dalam Ukhuwah?

Penelitian ini merupakan penelitian dengan metode penelitian kualitatif yang mana hasil penemuannya tidak terukur secara pasti, penelitian kualitatif memerlukan data lisan atau tertulis dan benda-benda yang diamati sampai detailnya (Arikunto, 2010: 22).

\section{LANDASAN TEORITIS}

Teori yang dijadikan landasan dalam penelitian ini ialah mengenai film, ukhuwah Islamiah dan tentang Semiotika. Film merupakan media audio visual penyampai pesan kepada kelompok melalui sebuah cerita yang dibuat dengan aturan tertentu.

Durasi Film terbagi menjadi dua, ada film panjang dan film pendek (Vera, 2015: 95). Film panjang merupakan film yang berdurasi lebih dari 60 menit, biasanya berdurasi 90-100 menit atau lebih, sedangkan film pendek merupakan film yang berdurasi kurang dari 60 menit. Film pendek biasanya jarang ditayangkan di televisi maupun bioskop. Film pendek biasanya dibuat bukan 
Representasi Ukhuwah Islamiah dalam Film Pendek

untuk komersialisme, namun tak jarang film ini dipasok ke rumah produksi atau saluran televisi (Effendy, 2009: 3)

Film sebagai media komunikasi tentu memiliki sebuah pesan di dalamnya, karena yang disebut media komunikasi yaitu alat untuk menyampaikan pesan. Arti dari pesan itu sendiri yaitu suatu materi yang dsampaikan oleh sumber kepada orang lain (Liliweri, 1991: 23).

Ada dua macam pesan dalam sebuah film yang ingin disampaikan kepada penonton, yaitu pesan secara langsung dan secara tidak langsung atau secara tersirat. Atau dengan istilah lain pesan dapat disampaikan secara implisit ataupun secara eksplisit.

Pesan yang disampaikam secara langsung ialah pesan yang secara jelas dijabarkan dalam percakapan atau tulisan, sedangkan pesan tersirat adalah pesan yang disampaikan ialah sebuah makna pesan yang tersembunyi.

Sebagai media dakwah film juga memiliki kelebihan tersendiri. Kelebihan tersebut ialah film memiliki tampilan yang berbeda yaitu tampilan audio, visual dan cerita yang dikemas, sehingga menarik untuk diperhatikan. Dengan demikian film sangat efektif untuk dijadikan sarana penyampaian pesan dakwah.

Film sebagai media dakwah ialah film yang kontennya bermuatkan nilai positif. Menurut Kharis Perdana dalam Republika (2018) ada empat kriteria film yang dapat dikatakan film positif. Pertama film itu tidak bertentangan dengan nilai ajaran Islam. kedua konten Film tidak mengandung unsur Pornogafi dan Pornoaksi, ketiga film itu memberi inspirasi dan tidak menimbulkan kontroversi dalam masyarakat, kemudian yang keempat film itu tidak harus bergenre religi, tapi bermuatkan nilai-nilai keislaman. Teruntuk pemeran dalam film, Uwes Fatoni (2008: 2) berpendapat bahwa pemain film Islam sebagai media dakwah tersebut dituntut untuk konsisten dalam berprilaku di kehidupan sehari-harinya. Artimya tidak bertolak belakang antara peran di film dan peran di dunia nyatanya.

Ukhuwah Islamiah sebagai salah satu pesan dakwah dinilai sangat penting untuk dikaji. Ukhuwah Islamiah secara bahasa berasal dari bahasa arab, Ukhuwah asal katanya yaitu kata أخ (akhun) yang berarti saudara, kata ukhuwah berarti persaudaraan atau kerukunan (Hasim, 1987: 164).

Ukhuwah Islamiah menurut Quraish Shihab (2005, 487) "Persaudaraan yang bersifat islami atau yang diajarkan oleh Islam”. Artinya Ukhuwah Islamiah bukan berarti persaudaraan sesama muslim, tapi persaudaraan yang diajarkan oleh Islam.

Ukhuwah Islamiah tidak sekedar persaudaraan dengan sesama orang Islam saja. Tetapi juga persaudaraan dengan setiap manusia di seluruh dunia meskipun berbeda keyakinan dan agama, karena Ukhuwah Islamiah merupakan persaudaraan yang dilandasi dengan nilai-nilai keislaman, seperti saling mengingatkan, saling menghormati, dan saling menghargai. 
Maulidah L, Muhlis A \& Fatoni U

Ukhuwah Islamiah sebagai salah satu pesan dakwah dinilai sangat penting untuk dikaji. Ukhuwah Islamiah secara bahasa berasal dari bahasa arab, Ukhuwah asal katanya yaitu kata أخ (akhun) yang berarti saudara, kata ukhuwah berarti persaudaraan atau kerukunan (Hasim, 1987: 164).

Ukhuwah Islamiah menurut Quraish Shihab (2005: 487) "Persaudaraan yang bersifat islami atau yang diajarkan oleh Islam”. Artinya Ukhuwah Islamiah bukan berarti persaudaraan sesama muslim, tapi persaudaraan yang diajarkan oleh Islam. Ukhuwah Islamiah tidak sekedar persaudaraan dengan sesama orang Islam saja. Tetapi juga persaudaraan dengan setiap manusia di seluruh dunia meskipun berbeda keyakinan dan agama, karena Ukhuwah Islamiah merupakan persaudaraan yang dilandasi dengan nilai-nilai keislaman, seperti saling mengingatkan, saling menghormati, dan saling menghargai.

Ada beberapa hak dan kewajiban ukhuwah Islamiah sebagai penguat adanya ikatan ukhuwah, diantaranya bersabar dalam menghadapi seseorang, meminta maaf dan memaafkan kekhilafan serta tulus dan ikhlas (Al-Khatib, 2006). Adapun Asy-Syaqawi (2013) menambahkan menganai hak dan kewajiban ukhuwah Islamiah yaitu membantu saudaranya, saling menyayangi, memberi nasehat, memberi salam atau menjawab ucapan salam.

Selain adanya penguat ukhuwah, terdapat pula beberapa faktor perusak ukhuwah. Faktor perusak ukhuwah Islamiah merupakan ancaman-ancaman yang menyebabkan perpecahan, sehingga seorang dengan seorang yang lainnya tidak rukun dalam persaudaraan. Dalam hal ini faktor perusak ukhuwah Islamiah yaitu bersikap tidak acuh, menegur seseorang di depan umum, dengki, tidak toleran, egois dan mudah marah, enggan menerima nasehat (Uqdah, 1996), serta mencaci atau mencela saudaranya (Sudirman, 2016: 122).

Mengkaji pesan Ukhuwah Islamiah dalam film salah satunya dikaji menggunakan analisis Semiotika. Kata Semiotika itu sendiri berasal dari bahasa Yunani, Semion yang berarti "tanda", atau Seme yang berati "penafsir tanda". Dari berbagai definisi di atas yang perlu digaris bawahi adalah bahwa semiotika sebagai ilmu menafsirkan tanda, tanda yang ada yaitu sebagai bentuk perwakilan makna yang dilihat dari objek.

Semiotika disebut Jhon Fiske (2012: 66) sebagai sebuah kajian mengenai tanda dan juga kajian tentang bagaimana tanda itu bekerja. Semiotika juga dapat diartikan tentang bagaimana suatu karya ditafsirkan oleh para pengamat dan masyarakat lewat tanda-tanda atau lambang-lambang. Semiotika sebagai ilmu tanda dan segala sesuatu yang berhubungan dengan cara berfungsinya, hubungannya dengan kata lain, pengertian dan penerimaannya oleh mereka yang menggunakannya (Sobur, 2001: 96). Maka jika sebuah tanda itu dikaji, maka pengkajian tersebut disebut semiotika. Pengkajian fungsi tanda serta hubungannya dengan seseuatu lain itu pun disebut semiotika.

Salah satu model semiotika adalah model Charles Sanders Peirce. Teori 
Peirce menjadi grnd theory dalam semiotika. Peirce mengungkapkan semiotika secara menyeluruh (Suherdiana, 2008: 376). Peirce memperkenalkan semiotika dengan konsep segitiga makna, yaitu berupa tanda (sign/representament), object, dan interpretant. Ketiga elemen itu saling mempunyai keterikatan satu sama lain.

Hubungan ketiga elemen ini gambarkan oleh Peirce sebagai berikut :

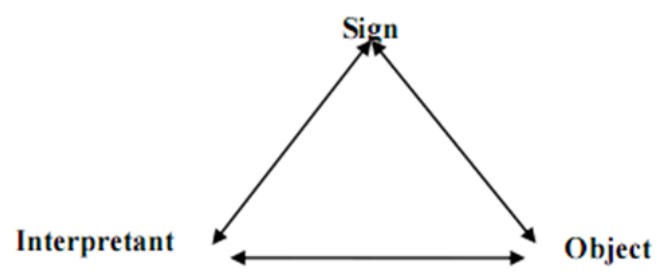

Gambar 1. Model Semiotika Peirce

Gambar 1 di atas menjelaskan bahwa ketiga elemen itu saling berkaitan dan tidak bisa dipisahkan. Sign/Representament yaitu bentuk yang diperoleh dari tanda atau berfungsi sebagai tanda, lebih jelasnya Representament terkadang diistilahkan juga menjadi tanda yang pertama dilihata atau didengar. Object yaitu sesuatu yang merujuk pada tanda (sign) itu. Maksudnya dalam bahasan object, tanda tersebut dirujuk seseuai dengan bentuk dari tanda yang ada. Sedangkan Interpretan, Maksudnya bukan penafsir tanda, tetapi lebih merujuk pada makna dari suatu tanda yang telah diketahui Objectnya.

Representasi melalui teori semiotika charlessanderspeirce, Peirce mendefinisikan representasi sebagai hubungan diantara tanda, objek dan interpretant. Ketiga elemen itu menurut Peirce akan memunculkan sebuah representasi.

Prinsip mendasar tanda bagi Peirce adalah sifat representatif, yaitu sifat yang mewakili sesuatu yang lain, dan juga sifat interpretatif yaitu tanda memberikan kebebebasan untuk bisa diinterpretasikan oleh pemakai tanda itu. (Rusmana, 2014: 107).

\section{HASIL DAN PEMBAHASAN}

Film Cinta dalam Ukhuwah disutradarai oleh Muhammad Amrul Umami seorang lulusan S1 Teknik Informatika IT Telkom Bandung. Film ini diproduksi oleh film maker muslim yang didukung oleh yayasan PPPA Daarul Quran, dan telah ditonton di Youtube sebanyak 272.834 kali (Part I), 236.271 kali (Part II), dan 181,323 kali (Part III). (diakses tanggal 6 februari 2019 pukul 10:08). Film ini bercerita tentang persahabatan dalam perbedaan, serta bagaimana meyikapi perbedaan dengan cinta dan persaudaraan. 
Maulidah L, Muhlis A \& Fatoni U

Produksi sebuah film tentu sangat membutuhkan sebuah tim untuk bekerja sama membuat film. Tim produksi ialah orang-orang yang membuatt film dengan job desk yang berbeda-beda.

Tim Poduksi Film Cinta dalam Ukhuwah diantaranya ada Andre M. Addin sebagai Line Producer yang bertugas untuk membuat anggaran dan menjaga cash flow dalam film ini. Penulis film ini ialah M. Ali Ghifari, dan yang menyutradarai ialah M. Amrul Ummami. Sutradara film ini memiliki dua asisten, yaitu Randie Anthony Hidayat sebagai Asisten sutradara 1, dan Ryan Hidayatullah sebagai asisten sutradara 2. Amrul Ummai selain sebagai sutradara, ia juga menjadi editor dalam film ini. Adapun pemimpin kamera dan yang mengelola pengambilan gambar dalam film ini ialah Ryan Kurniawan.

Tim produksi lainnya ada M. Iqbal sebagai Production Manager, Heri Junaedi sebagai Art Director and Stunt, kemudian Acting Coach oleh M. Ali Ghifari, Graphic Design oleh Gilang Bayu Rizkika, Assisten Production oleh Tulus Rega Wahyuni. Urusan make up dan Wardrobe dipegang Santika Adji, Anggia Widhi Astrian, Vivi Afifah, dan yang betanggung jawab mengenai perekaman suara ialah Ryan Hidayatullah, M. Iqbal, M. Ali Ghifari dan Andre M. Addin.

Adapun para tokoh pemain atau actor dalam film Cinta dalam Ukhuwah dibintangi oleh M. Ali Miqdad yang berperan sebagai Ariyo, M. Iqbal sebagai Sakti, Andre M. Addin sebagai Azzam, Latifah M. Hasan sebagai Anita, Vivi Afifah sebagai Kikin Sita, dan Ratri sebagai Najwa. Nama-nama ini ialah pemeran yang berperan banyak dalam film ini.

Pemain pembantu dalam film ini di antaranya yaitu Riesca Anita Fidya sebagai Fadhila, Rietsa Faiza sebagai Reina, Yadi Guccy sebagai Pak Dosen, Ahmad Rhezanav sebagai Anto, Evan Hanafiie sebagai Salim, Gilang Bayu Rizkika sebagai Wahyudi, Anggia Widhi Astriani sebagai bu Rere atau dosen TU, Sartika Adji sebagai bu Veve yang juga Dosen TU, M. Ali Ghifri sebagai Abang Anita, Heri Junaedi sebagai Ayah Azzam,dan Imerthi Gracia sebagai Mbak Kantin. Tim produksi dalam film ini memang terdapat seseorang yang memiliki rangkap job, namun job yang dirangkap tersebut tidak memiliki beban yang sama beratnya.

Setelah menganalisis keseluruhan film Cinta dalam Ukhuwah, Prosedur yang pertama kali dilakukan adalah mengidentifikasi adegan-adegan dalam film tersebut yang mengandung representasi pesan ukhuwah Islamiah. Penelitian ini menjelaskan apa yang menjadi fokus penelitian seperti yang disebutkan di atas. Metode yang diterapkan yaitu menggunakan analisis semiotika model Charles Sanders Peirce yang berkenaan dengan representament(tanda), object(acuan tanda), dan interpretant(penggunaan tanda).

Pertama dijabarkan data representament atau tanda berupa gambar adegan dan atau suara berupa dialog dalam adegan tersebut yang merepresentasikan ukhuwah Islamiah. Kemudian menjabarkan objectnya dan menginterpretasi tanda 
dan acuan tanda tersebut. Konsep Semiotika Charles Sanders Peirce ialah segitiga makna, yaitu Representamen, object, dan interpretant, yang mana ketiga elemen tersebut saling berkaitan satu sama lain.

Hasil penelitian ini menemukan adanya adegan perusak ukhuwah Islamiah dan adegan penguat ukhuwah Islamiah. Adegan perusak Ukhuwah Islmiah yaitu menurut Abu 'Ashim Hisyam bin Abdul Qadir Uqdah (2004) dan Sudirman (2016: 122). Adapun faktor penguat Islamiah yang dibahas yaitu mengacu pada konsep konsep Ukhuwah Islamiah Amin bin Abdullah asy-Syaqawi (2013: 9-10) dan konsep khuwah Islamiah Muhammad Al-Khatib (2006: 83-91).

Untuk memetakan adegan yang merepresentasikan ukhuwah Islamiah dalam film ini, maka diklasifikasikanlah ukhuwah Islamiah ke dalam dua bagian, yang pertama terkait adegan perusak ukhuwah Islamiah, kemudian yang kedua terkait adegan penguat ukhuwah Islamiah. Lalu adegan-adegan tersebut dicari apa saja representamentnya, bagaiamana object dan intepretantnya.

\section{Adegan Perusak Ukhuwah Islamiah}

Adegan aperusak ukhuwah Islamiah dalam film Cinta dalam ukhuwah merupakan ancaman-ancaman yang menyebabkan perpecahan, sehingga seorang dengan seorang yang lainnya tidak rukun dalam persaudaraan. Dalam hal ini faktor perusak ukhuwah Islamiah yaitu bersikap tidak acuh, menegur seseorang di depan umum, dengki, tidak toleran, egois dan mudah marah, enggan menerima nasehat (Uqdah, 1996), serta mencaci atau mencela saudaranya (Sudirman, 2016: 122).

Adegan pertama tentang perusak ukhuwah Islamiah yaitu menegur di depan umum. Adegan yang merepresentasikan faktor perusak ukhuwah Islamiah terkait menegur di depan umum terdapat pada menit ke 19:42 - 19:50.

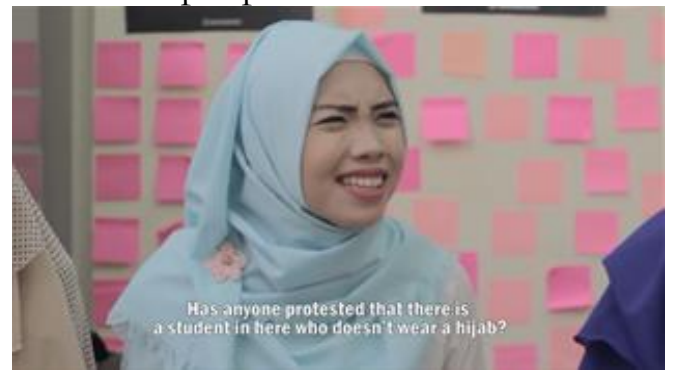

Sumber: Film "Cinta dalam Ukhuwah"

Gambar 2. Adegan menegur di depan umum

Representament dalam adegan gambar 2. menunjukan seorang perempuan bernama Kikin yang sedang berbicara "Mumpung Najwa ikut ngomong. Aku juga mau bahas. Kenapa sih gak ada yang protes, anak LDK ada yang gakpake jilbab”.

Object dalam adegan yaitu dalam ruangan LDK, ekspresi wajah Kikin 
Maulidah L, Muhlis A \& Fatoni U

berbicara terlihat kesal, di sebalah kiri dan kanan Kikin terdapat seseorang. Adapun interpretant Dialog pada representament di atas sikap Kikin memberi kesan ketidaksukaannya terhadap Najwa karena tidak memakai jilbab. Kikin menegur Najwa dihadapan orang banyak, dan membuat Najwa tersakiti dan malu, sehingga akan menimbulkan renggangnya persaudaraan antara Najwa dan Kikin.

Menegur seseorang di muka umum merupakan penyebab cepat pudarnya rasa cinta dan mudah menanam bibit-bibit permusuhan, karena merasa dicemarkan dan dihina, juga dapat menimbulkan sifat keras kepala dan nafsu untuk membalas dendam (Uqdah, 2004: 72). Walaupun tujuan Kikin baik, ia hanya ingin Najwa dapat menjalankan perintah Allah yaitu memakai jilbab, dengan cara memanfaatkan kesempatan agar Najwa malu dan segera berubah.

Adegan kedua terkait perusak ukhuwah Islamiah yaitu dengki. Direpresentasikan dalam adegan pada menit ke 27:10 - 27:17. Dengan Representament gambar berikut.

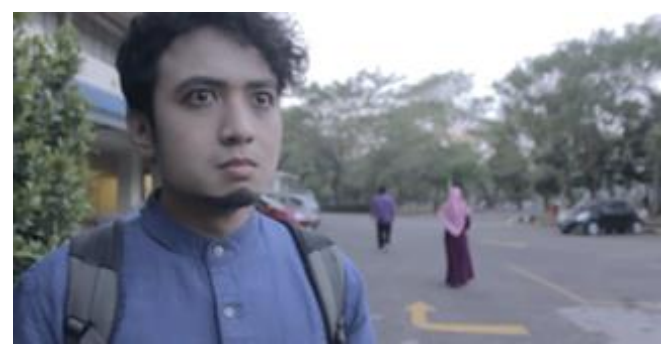

Sumber: Film "Cinta dalam Ukhuwah"

Gambar 3. Adegan dengki

Object dalam adegan yaitu Azam sedang cemberut, di belakang Azam terdapat satu orang laki-laki dan satu orang perempuan. Interpretantnya ialah Mimik wajah Azam merepresentasikan bahwa dia kesal melihat satu orang lelaki dibelakangnya yaitu Ariyo dan satu orang perempuan di belakangnya yaitu Anita. Azam menyimpan rasa dengki, maka tali ukhuwah antara mereka berduapun akan semakin rapuh dan merusak ikatan persaudaraan.

Azam seringkali merasa Ariyo adalah pesaingnya, padahal tidak ada ancaman apapun untuk Azam, itulah yang dirasakan seseorang yang menyimpan dengki, merasa ada pesaing padahal tidak disaingi Orang dengki biasanya tidak jernih lagi pemikirannya, sikapnya dalam menilai menjadi tidak objektif (Suhada, 2017).

Dengki merupakan sikap yang menaruh perasaan benci atau tidak suka terhadap seseorang atas dasar kecemburuan atau iri. Seperti apa yang dialami Azam dalam gambar 3. Azam merasa iri terhadap Ariyo karena Ariyo dekat dengan Anita, sehingga membuat Azam mempunyai perasaan dengki terhadap Ariyo.

Adegan ketiga tentang perusak ukhuwah Islamiah yaitu 
Sikap tidak toleran terdapat pada menit ke 03:13 - 03:38, dengan representament gambar berikut.

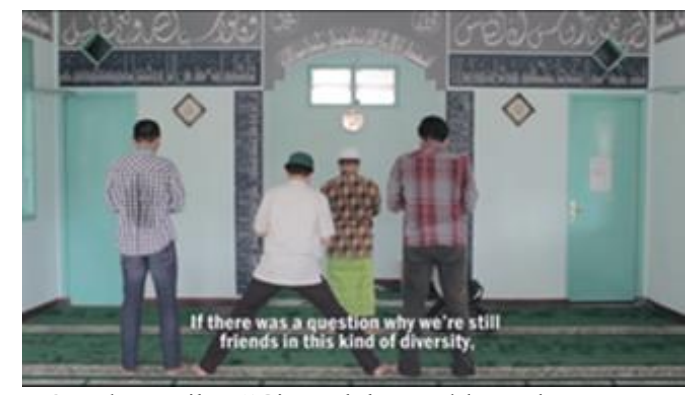

Sumber: Film "Cinta dalam Ukhuwah

Gambar 4. Adegan tidak toleran.

Gambar 4 di atas Objectnya ialah empat orang laki-laki sedang sholat di Musholla. Orang yang berdiri di tengah mengangkangkan kakinya agar nempel di kaki yang lain. Interpretant dari adegan teresebut ialah bahwa indakan seorang yang mengejar-ngejar kaki untuk ditempelkan merupakan tanda tidak toleran, begitu pun orang yang kakinya dikejar juga merupakan tanda tidak toleran. Sikap tersebut menunjukan tidak bisa menerima perbedaan, tidak saling menghargai satu sama lain. Hal tersebut tentu akan menimbulkan perpecahan dan merusak ikatan persaudaraan.

Azam dan Sakti dapat dikatakan kurang memilliki wawasan keilmuan yang luas, karena penyebab seseorang tidak memiliki rasa toleran ialah karena kurangnya wawasan keilmuan. Sebagaimana Casram (2016: 188) menyatakan toleransi harus didukung oleh pengetahuan yang luas, sikap terbuka, dialog, dan kebebasan berpikir.

Film Cinta dalam Ukhuwah ini sengaja menunjukan perbedaan, dan memberikan contoh bentuk tidak toleransi. Hal tersebut mengundang penonton untuk lebih memahami cara menyikapi perbedaan. Adegan tidak toleransi di atas merepresentasikan adanya faktor perusak ukhuwah Islamiah, karena tidak saling menghargai yang nantinya akan berpotensi pada terjadinya perpecahan.

Adegan ke empat terkait faktor perusak ukhuwah Islamiah ialah Egois dan Marah yang terdapat pada menit ke 07:05 - 07:33.

Representamen egois dan marah ditunjukan dalam sebuah dialog antara Azam kepada Aryo, "Berlebihan Antum yo, antum pikir antum siapa? antum nabi?" 


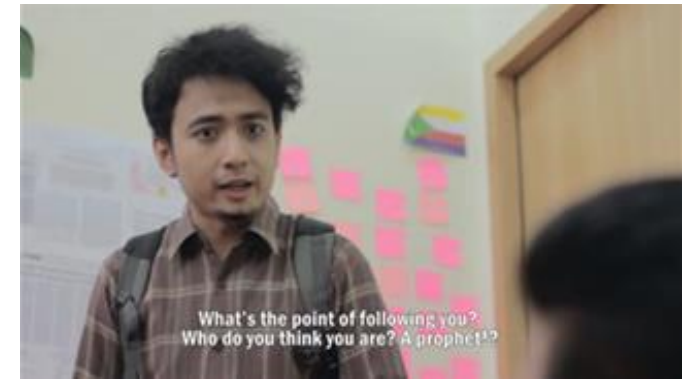

Sumber: Film "Cinta dalam Ukhuwah

Gambar 5. Adegan egois dan mudah marah

Dari representament gambar 5. di atas yang disebut objectnya ialah Azam sedang berbicara pada seseorang dihadapnnya dengan mimik wajah seperti marah. Intepretant yang didapat dari representamen dan object tersebut ialah Sikap Azam mereprsentasikan rusaknya ukhuwah Islamiah karena Azam egois dan marah. Kemarahan yang dialami Azam. diakibatkan oleh pengaruh keadaan sekitarnya, dibalik itu juga karena ada hal lain yang disembunyikan Azam, sehingga Azam makin mudah marah. Emosi marah yang dirasakan seseorang terka-dang meluap karena ada sesuatu yang tidak sesuai dengan kehendak seseorang itu, dan dapat mun-cul kapan saja pada setiap orang (Susanti, 2014: 104).

Marah dapat disebabkan oleh banyak hal, salah satunya adalah faktor keegoisan yang ada dalam diri seseorang. Adapun dampak dari adanya kemarahan yang dilakukan Azam dalam adegan di tabel 3.4 adalah dapat merusak ikatan ukhuwah, karena marah membawanya pada sifat kebencian terhadap seseorang, dan juga menimbulkan permusuhan.

Adegan ke-lima terkait faktor perusak ukhuwah Islamiah ialah Tidak acuh yang terdapat pada menit ke 16:15-16:20. Adegan terkait tidak acuh dengan representament berikut.

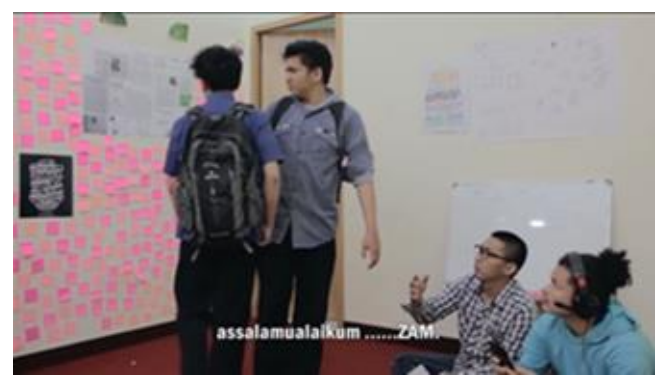

Sumber: Film "Cinta dalam Ukhuwah

Gambar 6. Adegan tidak acuh

Objectnya dalam gambar 6. di atas yaitu di dalam ruangan, Azam terlihat 
menabrakan tubuhnya ke tubuh Ariyo, Ariyo memperhaikan Azam, begitupun kedua temannya yang sedang duduk, dari representsment dan object tersebut, interpretanya ialah Azam tidak menjawab salam dan malah menyenggolkan tubuhnya ke tubuh Ariyo memberikan kesan bahwa rasa persaudaraan sudah luntur. Adegan pada gambar 3.5 merupakan representasi dari faktor rusaknya ukhuwah Islamiah dengan sikap tidak acuh atau cuek. Sikap Azam yang tidak menjawab salam dan menabrakan tubuhnya kepada Ariyo ialah sebagai tanda bahwa ikatan ukhuwah sudah lemah. Islam mewajibkan menjawab salam dari sesama muslim, namun yang dilakukan Azam ialah cuek dan tidak peduli padahal orang yang mendapatkan penghormatan dari orang lain, maka dia diwajibkan untuk membalas penghormatan tersebut dengan balasan yang lebih baik atau membalas dengan yang serupa (Hidayatullah, 2011: 90).

Keenam ialah adegan mencaci yang terdapat pada menit ke 20:05-20:09. Representament terkait mencaci sebagai berikut.

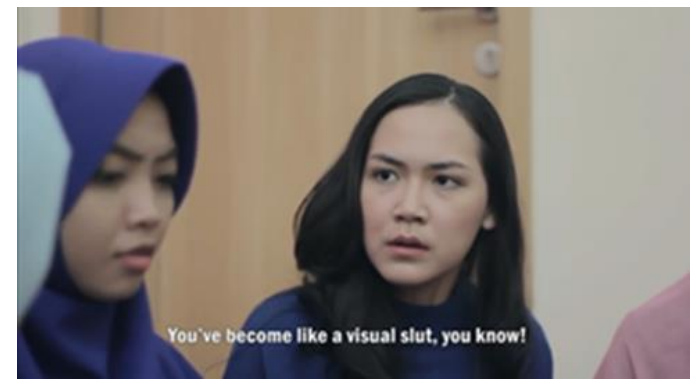

Sumber: Film "Cinta dalam Ukhuwah

Gambar 7. Mencaci

Adegan reprsentament gambar 7. di atas memberikan object berupa Sosok Najwa sedang mendengarkan seseorang di yang berbicara dengannya, Najwa memberi ekspresi wajah kaget. Dalam gambar terlihat tiga orang lainnya di dekat Najwa.

Representament dan object tersebut memberikan interpretant bahwa Kikin menyebut Najwa dengan kata pelacur visual, ini merupakan sebuah cacian atau celaan yang menyakiti persaan Najwa. Ketika hati seseorang telah tersakiti, maka tandanya ikatan tali ukhuwah semakin memudar.

Mencaci dalam Kamus Besar Bahasa Indonesia (Adi, 2001: 95). diartikan dengan "mencacat keras, mencela, memaki, menistakan, mengeluarkan perkataan yang tidak sopan". Kata yang terlontar dari Kikin merupakan bentuk perkataan yang tidak sopan, dan menyakitii perasaaan Najwa. Dampak dari pencacian yang dilakukan Kikin kepada Najwa ialah menyebabkan ikatan ukhuwah luntur. diantara kedua belah pihak akan lahir pertengkaran mulut, lahir permusuhan pribadi, rusaknya hubungan ukhuwah diantara mereka berdua (Masyur, 1994: 201). 
Maulidah L, Muhlis A \& Fatoni U

Adegan ketujub terkait faktor perusak ukhuwah Islamiah ialah enggan menerima nasehat terdapat pada menit ke 12:01-12:06. Representament enggan menerima nasehat ditunjukan dalam sebuah dosen "Lebay, orang genit dikit kok dibilang pelecehan"

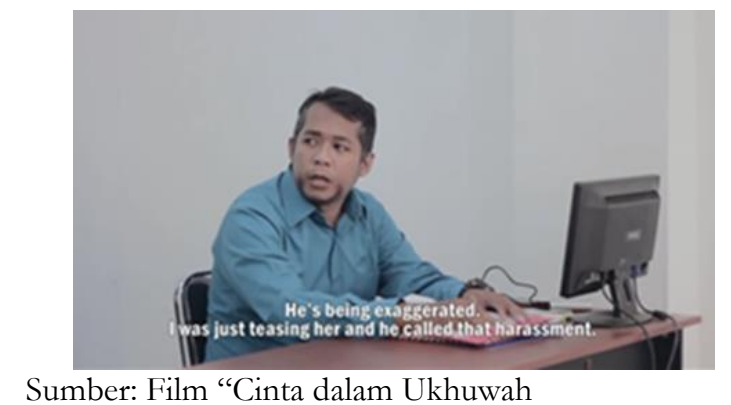

Gambar 8. Adegan enggan menerima nasehat

Object yang di dapat dari representament pada gambar 8. di atas ialah di ruang kuliah pak dosen dengan posisi duduk sedang melontarkan perkataan kepada seseorang. Intrpretannya ialah Terlihat dari perkataan yang dilontarkan pak Dosen. Pak dosen menunjukan sikap tidak terima telah dikatakan berbuat pelecehan. Ia enggan menerima nasehat dan malah membenci yang menasehatinya.

Enggan menerima nasehat akan membuat Ariyo sebagai orang yang menasehatinya merasakan adanya dinding pemisah antara orang yang dinasehatinya. Jika pak dosen enggan menerima nasehat, maka ia akan menggap Aryo adalah orang yang sombong dan merasa paling benar. Dari sinilah akan muncul bibit-bibit benci terhadap orang yang menasehatinya, yang nantinya orang yang dinasehati akan tidak mau melanjutkan ikatan persaudaraan dengan orang yang menasehatinya (Uqdah, 2004: 60).

Adegan di atas merepresetasikan faktor yang akan merusak ikatan ukhuwah. Dosan tersebut enggan menerima nasehat karena merasa lebih tua dan lebih berilmu dari yang menasehatinya, sehingga hal ini malah memunculkan rasa benci dan ketidaksukaan terhadap Ariyo yang menasehatinya.

\section{Adegan Penguat Ukhuwah Islamiah}

Penguat Ukhuwah Islamiah merupakan suatu hal yang akan menjadikan ikatan ukhuwah semakin terjaga dan semakin kuat. Penguat Ukhuwah Islamiah erat kaitannya dengan hak dan kewajiban ukhuwah Islamiah, yaitu hal yang harus dimiliki dan yang harus dipenuhi dalam menjalankan ikatan persaudaraan. Artinya hak dan kewajiban ukhuwah Islamiah adalah sebagai penguat ukhuwah itu 
Adegan pertama terkait faktor penguat ukhuwah Islamiah ialah menasehati yang terdapat pada menit ke 04:18- 04: 27.

Representament ditunjukan oleh dialog Ariyo, "Lu juga sak, kalo ada orang nempelin kakinya ke elu tahan sisinya, jangan lu ngejauh sampe ngerusak saff. Coba jabat tangan gue sak. Ukhuwah itu kaya jabat tangan. Baru terjadi kalau keduanya punya niat bertoleransi, keduanya siap mengalah"

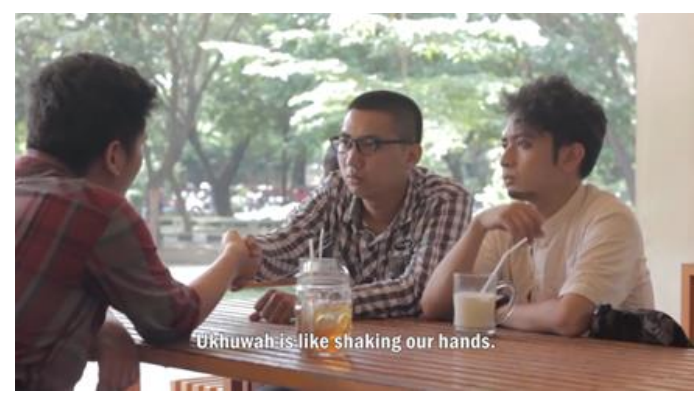

Sumber: Film "Cinta dalam Ukhuwah

Gambar 9. Adegan Menasehati

Object dari representament dari gambar 9 ialah Ariyo sedang berbicara dengan Sakti sambil berjabat tangan. Sebelah Sakti ada Azam terlihat sedang menyimak. Interpretantnya ialah Ariyo ingin menyatukan perbedaan dengan cara saling bertoleransi, saling menghargai. Sebab, itulah salah satu faktor kuatnya ukhuwah Islamiah, sedangkan dari perkataan Azam yang mengilustrasikan Ukhuwah seperti jabat tangan itu memberikan makna bahwa ukhuwah merupakan jalan bersatunya umat.

Syaikh Amin As-Syaqawi (2013: 9) menyebutkan saling menasehati sebagai hak dan kweajiban ukhuwah Islamiah, ia pun menyebutkan sebuah hadis yang disebutkan oleh Imam Bukhari dan Muslim, sebuah hadits dari Jarir radhiyallahu 'anhu, beliau menceritakan: "Aku membai'at Rasulallah Shalallahualaihi wa sallam shalallahu 'alaihi wa sallam untuk mengerjakan sholat, mengeluarkan zakat, dan memberi nasehat bagi tiap muslim". HR Bukhari no: 57. Muslim no: 56.

Adegan kedua terkait penguat ukhuwah Islamiah ialah saling menyayangi terdapat pada menit ke 40:53 - 40:56. Representament saling menyayangi sebagai berikut 


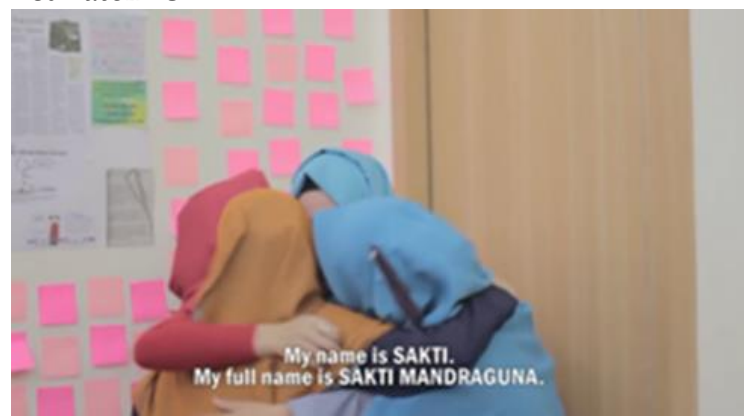

Sumber: Film "Cinta dalam Ukhuwah

Gambar 10. Saling Menyayangi

Object yang terdapat dari representament gambar 10. di atas ialah di sebuah ruangan empat orang nita memakai jilbab saling berpelukan. Interpretantnya ialah bahwa berpelukan menunujkan tindakan kasih sayang. Tindakan berpelukan itu memberikan pesan non verbal yang melambangkan arti keakuran atau kerukunan. Seakan tidak ada saling benci, saling bermusuhan. Tidak ada perpecahan yang ada hanya jalinan saling menyayangi.

Adegan tersebut merepresentasikan adanya ikatan ukhuwah Islamiah yang terlihat saling menyayangi. Saling menyayangi berarti tidak ada permusuhan, dan tidak ada saling membenci. Seorang muslim dengan muslim lainnya adalah bersaudara, jadi tidak sepatutnya ada kebencian pada antara satu dengan yang lainnya. Syaikh Amin As-Syaqawi (2013: 7) menyatakan saling menyayangi termasuk keharusan dari bingkai Ukhuwah Islamiah.

Adegan ketiga terkait faktor penguat ukhuwah Islamiah yaitu menolong yang terdapat pada menit ke 17: 16-17-21. Representament menolong ditunukan pada gambar berikut.

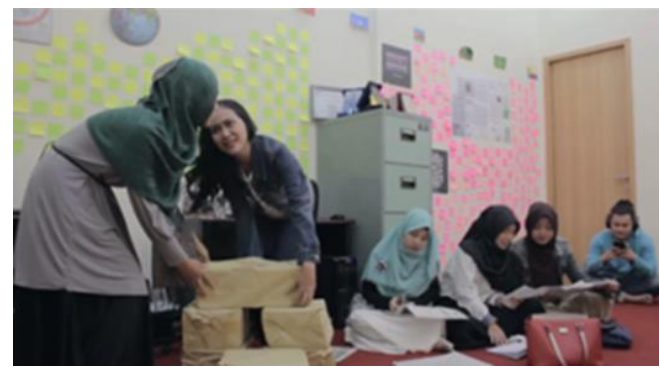

Sumber: Film "Cinta dalam Ukhuwah

Gambar 11. Menolong

Object yang terdapat pada representament gambar di atas ialah di suatu ruangan Anita dan Najwa mengangkat barang berbentuk kotak, disebelahnya terdapat tiga orang wanita berjilbab dan satu orang lelaki, semua terlihat fokus 

dengan aktifitasnya masing-masing. Interpretant dari adegan tersebut ialah bahwa adegan tersebut merepresentasikan adanya penguat ukhuwah Islamiah dalam hal membantu yang membutuhkan bantuan. Adegan Anita menolong Najwa merupakan tanda adanya ukhuwah yang baik.

Sikap Anita menolong Najwa dalam adegan akan memuculkan pemikiran Najwa tentan Anita, yang akan membawa Anita dan Najwa pada jalinan ukhuwah yang kuat, karena interaksi perilaku menolong yang dilakukan antara individu satu dengan individu lainnya akan memberikan suatu pengalaman yang dapat merubah penilaian terhadap diri mereka (Putra, 2015: 200).

Adegan ke empat faktor penguat ukhuwah Islamiah ialah bersabar menghadapi seseorang, yang terdapat pada menit ke 34: 53- 34:56. Representament ditunjukan dari perkataan Ariyo: "Yaudahlah gak apa-apa, saling bales kan gak nyelesain masalah"

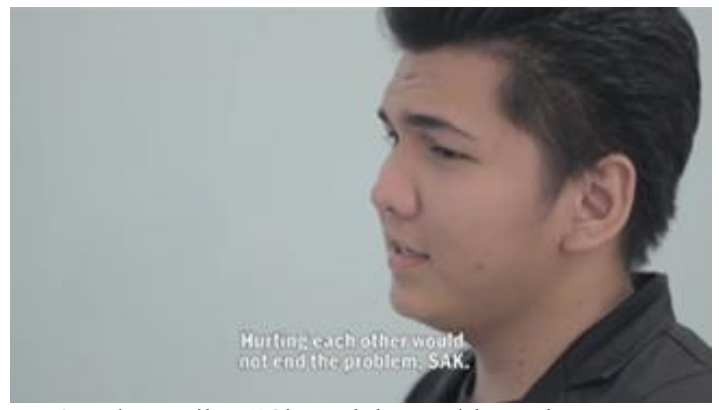

Sumber: Film "Cinta dalam Ukhuwah

Gambar 12. Bersabar menghadapi seseorang

Object dari represntament gambar 12. tersebut ialah sosok Aryo yang sedang berbicara. Interpretantnya yaitu Apa yang dibicarakan Ariyo menunjukan bahwa ia tidak ingin memperumit atau memperpanjang masalah yang nantinya malah akan menimbulkan permusuhan sehingga jalinan ukhuwah terputus. Sikap sabar yang dicerminkan dalam adegan pada tabel merupakan cara untuk mengindari segala bentuk permusuhan atau pertengkaran, yang nantinya akan memicu terputusnya tali ukhuwah. Syofrianisda (2017: 139) mengartikan sabar salah satunya sebagai sikap menahan diri dari segala macam dorongan hawa nafsu dan mempunyai sikap mental tahan uji. Hal ini seperti yang dilakukan Azam pada dialog dari representament di atas.

Adegan ke lima penguat Ukhuwah Islamiah ialah memberi salam terdapat pada menit ke 06: 54- 06-58. Representament memberi salam ditujukan dengan gambar adegan berikut. 


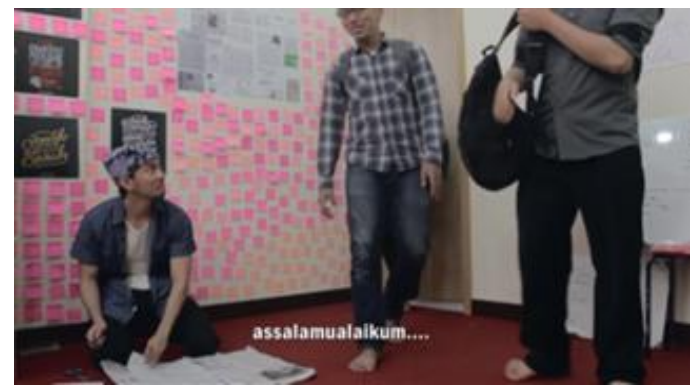

Sumber: Film "Cinta dalam Ukhuwah

Gambar 13. Mengucapkan salam

Object dari representament adegan pada gambar 13. di atas ialah Ariyo dan Sakti sedang masuk ke ruangan yang dihiasi kertas-kertas berwarna merah muda, Ariyo dan Sakti mengucapkan "Assalamualaikum", di ruangan tersebut terlihat temannya meperhatikan kedatangan mereka berdua. Interpretantnya ialah ucapan salam merupakan bentuk saling menghormati dan mendoakan, jika uacapan salam masih terjaga adanya, maka tandanya ikatan ukhuwah masih terasa kokoh, dengan salam akan lahir ketentraman dan kedamaian sehingga akan memperkuat ukhuwah Islamiah (Imran, 2013: 60).

Adegan ke enam tentang penguat ukhuwah Islamiah ialah meminta maaf yang terdapat pada menit ke 17: 57-18:00. Representament adegan meminta maaf ditujukan suara/dialog, "Gue minta maaf Zam kalau ada salah" dan gambar adegan berikut

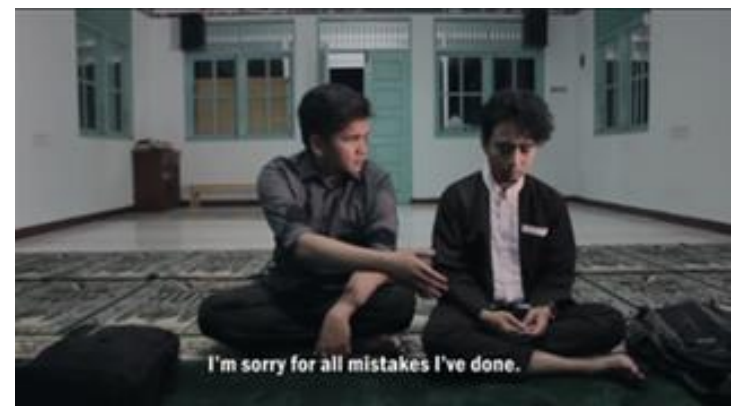

Sumber: Film "Cinta dalam Ukhuwah

Gambar 14. Meminta maaf

Object dari representament gambar 14 tersebut ialah di tempat sholat Ariyo dan Azam duduk, Aryo sedang meminta maaf kepada Azam dengan memberikan jabat tangan. Interpretantnya ialah Merepresentasikan adanya ukhuwah Islamiah dengan meminta maaf. Meminta maaf merupakan tindakan agar tidak terjadi permusuhan antara Ariyo dan Azam, yang mana dengan permusuhan diantara mereka akan merusak ikatan ukhuwah.

Tujuan meminta maaf untuk membangun hubungan yang lebih baik lagi 
dan agar tidak adanya sebuah permusuhan serta dendam. Hal ini selaras dengan pendapat Khasan (2013: 76) bahwa tujuan menghapuskan dan melupakan kesalahan yaitu karena adanya motivasi untuk membangun hubungan yang lebih baik.

Adegan ke tujuh tentang penguat ukhuwah Islamiah ialah tulus dan ikhlas yang terdapat pada menit ke 39: 19 - $39: 31$.

Representament ditunjukan oleh suara/dialog "Yo, Ane ini sahabat antum, walau kita sering beda pendapat, kalau Anita suka sama antum, dan antum sebaliknya. Ya kenapa ana harus salahin kalian berdua. Kalau antum khawatirin biaya nikah, Ana punya tabungan nikah. Niatnya buat nikahan ana, tapi kalau antum gak keberatan, antum bisa pake tabungan biaya nikah ana. Tapi Ana minta satu hal Yo. Bahagian Anita", dan gambar berikut.

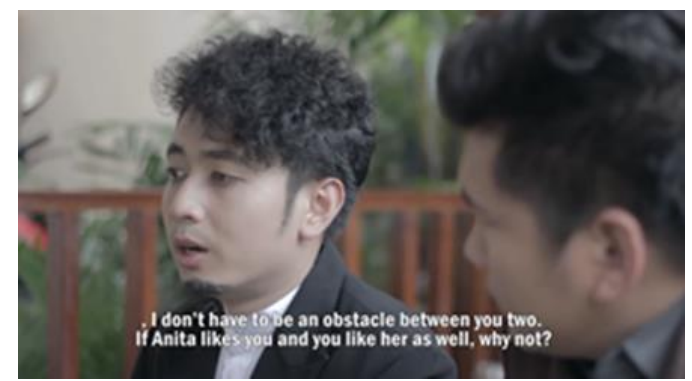

Sumber: Film "Cinta dalam Ukhuwah

Gambar 15. Tulus dan Ikhlas

Object dari representament dari gambar 15. tersebut ialah Aryo sedang berbicara dan diperhatikan oleh Azam. Interpretannya ialah sebuah ketulusan dan keikhlasan. Ucapan Azam tidak mengatakan bahwa ia tulus, namun Azam secara tidak langsug menyimbolkan bahwa ia sangat tulus merelakan Anita menikah dengan Ariyo walaupun sebelumnya Azam telah melamar Anita untuk menjadi istrinya. Pemberian Azam yang dilakukan tanpa mengharapkan pamrih dari Ariyo akan menimbulkan dampak prilaku yang baik terlebih terhadap jalinan ukhuwah. Karena menghiasi setiap pikiran dengan ketulusan maka hati akan melahirkan perilaku yang baik (Tanjung, 2015: 25).

Semua adegan dalam flm Cinta dalam Ukbuwah yang berkaitan dengan ukhuwah Islamiah baik sebagai perusak ataupun penguat ukhuwah berasal dari jiwa dan lidah. Faktor perusak ukhuwah yang direpresentasikan dalam film Cinta dalam Ukhuwah karena tokoh tidak merawat jiwa dan lidah yang tak dikendalikan (Sudirman, 2016: 123). Adapun faktor penguat ukhuwah Islamiah maka jiwa dari tokoh sudah terawat dan lidah yang mampu dikendalikan. 


\section{PENUTUP}

Berdasarkan hasil penelitian dan pembahasan yang telah dibedah menggunakan analisis Semiotika Charles Sanders Peirce tentang representasi ukhuwah Islamiah dalam Film Cinta dalam Ukhuwah, dapat ditarik kesimpulan sebagai berikut:

Terdapat ditemukan 14 tanda yang merepresentasikan tentang adanya pesan ukhuwah Islamiah yang mengacu pada konsep perusak Ukhuwah Islmiah yaitu menurut Abu 'Ashim Hisyam bin Abdul Qadir Uqdah dan Sudirman Adapun penguat Islamiah yang dibahas yaitu mengacu pada konsep konsep Ukhuwah Islamiah Amin bin Abdullah asy-Syaqawi dan konsep khuwah Islamiah Muhammad Al-Khatib.

Representament, Object dan interpretant yang ada dalam 14 adegan tersebut menyatakan bahwa representasi ukhuwah Islamiah yang terdapat dalam film Cinta dalam Ukhuwah semua berkaitan dengan akhlak yang diperankan tokoh. adegan yang diberikan dalam film ini menemukan representasi adanya perusak ukhuwah Islamiah dan penguat ukhuwah Islamiah. Diantaranya yang tadinya menegur di depan umum, dengki, tidak toleran, egois dan mudah marah, tidak acuh, mencaci, dan enggan menerima nasehat lalu menjadi menasehati, saling menyayangi, meolong, bersabar menghadapi seseorang, memberi salam, meminta maaf, dan tulus serta ikhlas. Walaupun tidak secara langsung ke 14 representament adegan ukhuwah Islamiah tersebut menyebutkan makna ukhuwah Islamiah sesuai landasan konseptual.

Penerapan penelitian ini diharapkan masyarakat lebih faham tentang arti penting ukhuwah Islamiah, dan mengaplikasikan factor-faktor penguat ukhuwah Islamiah, serta selalu kritis mengkaji makna mendalam dari pesan film agar selalu bisa mengambil hikmah dan pelajaran serta dapat diaplikasikan dalam kehidupan. Bagi para sineas yang hendaknya membuat isi pesan film yang lebih menarik dan bermafaat yang mengandung nilai-nilai keislaman, agar membawa masyarakat indonesia terkhusus umat Islam pada kebaikan-kebaikan.

Bagi peneliti selanjutnya diharapkan dapat meneliti film dari aspek lain yang lebih menarik lagi, agar pegkajian film semakin berkembang.

\section{DAFTAR PUSTAKA}

Adi, D. K. (2001). Kamus Praktis Bahasa Indonesia, Surabaya: Fajar Mulya.

Al-Khatib, M. A. (2006). Model Masyarakat Muslim: Wajah peradaban masa depan, Bandung: Prorgressio.

Aminah, S. (2016). Merajut ukhuwah Islamiah dalam Keanekaragaman Budaya dan Toleransi antar Agama, Jurnal Cendekia, Vol.13, No.1, 2016

As-Syaqawi, Amin bin Abdullah. (2013). Ukhuwah Islamiah, Terj. Abu Umamah Arif Hidayatullah. Islamhouse.com

Chirzin, M. (2007). Ukhuwah dan Kerukunan dalam Perspektif Islam, Aplikasia, 
Jurnal Aplikasi llmu-ilmu Agama, Vol. VIII, No. 1 Juni 2007.

Casram. Membangun Sikap Toleransi Beragama dalam Masyarakat Plural, Wawasan: Jurnal Ilmiah Agama dan Sosial Budaya 1-2 Juli 2016.

Effendy, H. (2009). Mari Membuat Film, Panduan Menjadi Produser, edisi kedua, Jakarta: Erlangga.

Fatoni, U. (2008). Menanti Film Dakwah Berkualitas, dalam Republika Online. Diakses $24 \quad$ juli 2018, dari https://www.academia.edu/8139016/Menanti_Film_Dakwah_Berkualitas _Republika_22_Februari_2008_

Fiske, J. (2012). Pengantar Ilmu Komunikasi, Jakarta : Raja Grafindo Persada.

Hasim, M. E. (1987). Kamus Istilah Islam, Bandung: Pustaka.

Khasan, M. (2017). Perspektif Islam dan Psikologi Tentang Pemaafan, Jurnal at-Taqaddum, Vol. 9, No. 1, Juli 2017.

Latif, R. Utud, Yusiatie, (2013). Kamus Pintar Broadcasting, Bandung: Yrama Widya.

Liliweri, A. (1991). Memahami peran Komunikasi Massa dalam Masyarakat, Bandung: Citra Aditya Bakti.

Masyur, K. (1994). Membina Moral dan Akhlak, Jakarta: Rineka Cipta

Perdana, K. 2018. Nasib Film Islami di Negeri Mayoritas Muslim. Dalam Republika Online, diakses 24 Juli 2018, dari https://www.republika.co.id/berita/nasional/news-

analysis/18/04/19/p7fj6g415-nasib-film-islami-di-negeri-mayoritasmuslim

Shihab, M. Quraish. (2005). Wawasan Al-Quran : Tafsir Maudhu'i atas Pelbagai Persoalan Umat, Bandung: Mizan

Sobur, A. (2001). Analisis Teks Media, Suatu Pengantar untuk Analisis Wacana, Analisis Semiotik, dan Analisis Framing, Bandung: Remaja Rosa Karya.

Sudirman, C. (2016). Ukhuwah Islamiah sebagai Pondasi Terwujudnya Organisasi yang mandiri dan Profesional. Jurnal Pendidikan Islam. Vol. 14. No. 1. Tahun 2016.

Rusmana, D. (2014). Filsafat Semiotika, Bandung : Pustaka Setia

Suherdiana, D. (2008). Konsep Dasar Semiotika dalam Komunikasi Masa Menurut Charles Sanders Peirce, Jurnal Ilmu Dakwah: Academic Jurnal for Homiletic Studies, Vol. 4 No. 12. Juli-Desember 2008

Susanti, R. dkk. (2014). Perasaan Terluka Membuat Marah, Jurnal Psikologi, Vol. 10, No. 2, Desember 2014

Suhada. (2017). Sifat Dengki. Diakses 31 Juli 2018, dalam Kompas, https://edukasi.kompas.com/read/2017/08/08/08060011/sifat-dengki.

Syofrianisda, (2017). Konsep Sabar Dalam Al-Qur'an Dan Implementasinya dalam Mewujudkan Kesehatan Mental, HIKMAH: Jurnal Pendidikan Islam, Vol. 6, No. 1 Januari - Juni 2017 
Maulidah L, Muhlis A \& Fatoni U

Tanjung, Rani Darma Sakti (2015). Model Ketulusan (Altruistic) Bidan Dalam Memberikan Pelayanan. Jurnal Pendidikan dan Kepengawasan, Vol 2 No. 1 April 2015

Uqdah, Abu 'Ashim Hisyam bin Abdul Qadir, (1996). Virus-Virus Ukhuwah, Jakarta: Robbani Pers.

Vera, N. (2015). Semiotik dalam Riset Komunikasi, Bogor: Ghalia Indonesia. 